\title{
Social Production of Space: "Lived Space” of Informal Livelihood Operators; the Case of Dares Salaam City Tanzania
}

\author{
Nelly John Babere \\ Ardhi University, Dar es Salaam, Tanzania \\ Email: gathiharry@gmail.com, gathi2000tz@yahoo.co.uk \\ Received 23 September 2015; accepted 27 October 2015; published 30 October 2015 \\ Copyright (c) 2015 by author and Scientific Research Publishing Inc. \\ This work is licensed under the Creative Commons Attribution International License (CC BY). \\ http://creativecommons.org/licenses/by/4.0/ \\ (c) (i) Open Access
}

\begin{abstract}
This paper critically examines the social production of space for informal livelihood activities. While many progressive scholars have embraced the idea of eviction and harassment of the informal livelihood operators, what these scholars have often left unexplored is how informal operators contribute to the social production of space in urban areas. The first half of this paper focuses on the idea of Lefebvre's conceptualisation of social production of space and the linkage with the informal livelihood activities. The second section focuses specifically on how social production of space is manifested in the operation of the informal livelihood operators. I argue that informal mode of production of space should be considered to inform how spaces for such activities are produced.
\end{abstract}

Keywords

Production of Space, Lived Space, Informality and Livelihoods

\section{Literature Review}

\subsection{Social Production of Space}

In this paper the production of space takes place through a combination of the process of appropriation and regulations. I will start by drawing from Lefebvre's argument about how spaces are produced. Lefebvre rejects the dominant philosophical and scientific conception of space in order to develop a critical knowledge of space, which, overcoming the separation of concepts and reality, is instead based on the joint concept and reality of the production of space (Kerr, 1994: pp. 23-24). According to UnWin (2000: p. 14) Lefebvre’s new conceptualisa- 
tion is aimed at challenging previous ways of understanding how spaces are produced. Furthermore, Lefebvre argues that social relations are spatial and connected to social space; and the science of space has failed to incorporate social relations. Within the social world, of which physical space is a part, socio-economic characteristics of human agency illuminate the physical place and show how it is lived (Kerr, 1994). As cited in Kidder (2009: p. 311), Soja (1989) provides an overall insight into the social relevance of spaces as socio-spatial dialectic: "social relations of production are both space forming and space contingent". Lefebvre argues that a conceptual triad is vitally important in understanding the process of producing spaces (Lefebvre, 1991). The production of space therefore underlines the duality of space as on the one hand, the space of philosophy and on the other, and the space of those who confront and constitute the spatiality of everyday life. However, it goes beyond this dichotomy of conceived and lived space by introducing a third concept, that of perceived space. Lefebvre treats space as a product of social relations as well as a social political product (Lefebvre, 1991: p. 287). He brings together objective and subjective understandings of space by referring back to the processes through which space is produced. The following section provides an overview of the conceptual triad of space as summarised by Kerr:

1. Spatial practice: The spatial practice of a society secretes that society's space; it propounds and presupposes it, in a dialectical interaction; it produces it slowly and surely as it masters and appropriates it. Spatial practice embraces production and reproduction, and the particular locations and spatial sets characteristic of each social formation. Spatial practice ensures continuity and some degree of cohesion.

2. Representations of space: This is conceptualised space, the space of scientists, planners, urbanists, technocratic sub-dividers - all of whom identify what is lived and what is perceived with what is conceived. This is the dominant space in any society and is tied to the relations of production and to the "order" which those relations impose and hence to knowledge, to signs, to codes, and to "frontal" relations. Particularly important is the spatial ordering of towns and cities, as well as the individual buildings.

3. Representational spaces: This is space as directly lived through its associated images and symbols, and hence the space of "inhabitants" and "users". This is the dominated-and hence passively experienced-space which the imagination seeks to change and appropriate; it overlays space, making symbolic use of its objects. Representational spaces need obey no rules of consistency or cohesiveness. Redolent with imaginary and symbolic elements, they have their source in history - in the history of a people as well as in the history of each individual belonging to the people. Representational spaces thus may be said to tend towards more or less coherent systems of symbols and signs, sometimes coded, sometimes not, linked to the clandestine or underground side of social life, as also to art (Kerr, 1994: p. 26).

According to Kerr (ibid.) for Lefebvre, then, spatial practice, representations of space and representational spaces contribute in different ways to the production of space according to their qualities and attributes, according to the society or mode of production in question and according to the historical period. Kidder (2009) in his analysis followed this framework for his work on appropriation of space by bike messengers in New York City. He argues that spaces can be appropriated by users against their intended conception and emphasises how space is better understood as it is lived. As cited in Kidder (2009: p. 309), Gieryn (2002) suggests that space is shaped by those who use it but also, that space shapes the actions of those within it. Following Lefebvre's conceptualisation of the social production of space, emphasis is directed towards the material dimension as useful in defining the historical emergence and political/economic function of urban space. Space is not only determining but also can be determined.

As noted above, production of space allows three different worlds of discourse and knowledge systems to simultaneously claim the future of a piece of land. For informal operators this space is of vital importance for their economic life whilst for the municipality the same space is a planning area, an abstract space, as Lefebvre referred to it, which is ready to be transformed in order to accomplish political goals. Both operators and the municipality look upon the same space, albeit in different ways, and hence create conflicting rationalities in terms of the logic of survival on the side of informal operators and the logic of governance on the side of the municipality (Watson, 2009). The operators' representational space is based on everyday experience and practices, which provide a different meaning from the representation of space as dictated by the municipalities. For the operators, the experience of losing such space becomes a matter of contestation with the municipality. Beyond this tension, there are other stakeholders involved, including the local shopkeepers and the shoppers themselves, all of whom contribute to the production of space in prime locations.

The municipal representation of the lived space of the operators is usually framed against the political reality 
of aesthetic issues, public health concerns, land values, competiveness and congestion. The municipal plans unveil a political, economic and legal construction of space, regardless of the involvement of different actors in creating its meaning. In order to transform the space used by informal operators, the municipality is obliged to abstract it from the operators' domain of experience and represent it in terms of pedestrian walkways, road reserves or isolated locations in the peripheral area, perceived as alternative locations for informal activities. This approach underlies spatial practice on the issues pertaining to informal livelihood activities, and hence becomes a form of knowledge understood by practitioners and other people within society who lack any personal experience of informal practices. The following section provides the history of the perceived space, the space of planners, in relation to informal activities.

\subsection{Production of Space for Informal Sector Activities}

The history of planning practices as observed by Cross and Morale (2007) pinpoints a key text by Le Corbusier (1923) which expressed the modernist vision aiming at the creation of an ideal society through planned structures, in which issues of plot division, individual ownership and regulation were addressed to tackle shapeless communities, poverty and disorder, problems which were exacerbated during the industrial revolution in Europe. From that time onwards, planners were those endowed with the necessary scientific and technological skills to produce master plans and detailed plans for city management (Hirt, 2009). Modernist land use planning practices have been influenced not only by Le Corbusier but also by other influential figures in the history of urban planning, such as Ebenezer Howard, who emphasised areas which required specific attention such as housing, infrastructure development, public transport and regulation of the built environment (Beall \& Fox, 2009). The main aim has been that of addressing public health problems and bringing aesthetic improvements to the cities through urban design (Talvitie, 2009). Following the colonial period, the master planning approach was not only implemented in developed countries, but also in developing countries (Beall \& Fox, 2009). Colonial governments also prepared master plans in their respective countries to manage city growth (Mabogunje, 1990); for instance the first master plan for Dar es Salaam City was prepared in 1949 (Šliužas, 2004). Despite their undeniable presence, informal activities were left out of the formal processes of architecture and urban planning in the modern world. From this omission, it is clear that informal livelihood activities were given little or no room in that period, as everything was to be planned, efficient and structured.

Although informal activities were given little or no attention in the modern era, they continued to grow (Verick, 2006; Sparks, 2010). When incorporating the idea of modernization as prevalent in the western world, developing countries faced direct challenges in terms of their informal livelihood operators. City managers saw them as clear signs of disorder and unruliness, as noted by Cross and Morales (Cross \& Morales, 2007). In African countries, modernist planning was dominated by top-down, comprehensive and rigid planning practices (Kamete, 2008). According to Perry (2003) in the process of producing spaces, planners in African countries also ensured that "modern urban life is carried out in planned society". In the development vision of the modern world, informal livelihood activities were seen as backward, inefficient and detrimental to national development schemes, as planning aimed at pursuing the overall objective of shaping, guiding and governing the behaviour of others in urban spaces (Kamete, 2008; Kamete, 2012). Colonial practices regarding the production of spaces continued in almost all colonies and continued to be manifested once colonised countries had gained independence. As noted by Roy (2010) informality in African cities has influenced the production of spaces outside the norms of planning and architecture and hence plays a fundamental role in shaping the city image. However the informal livelihood operators seem to have succeeded, against competition with both modern retail outlets and the local authorities, to find and maintain a position for themselves in urban spaces. As argued by Gans (2002), the use of space is socially determined but not the shape of space. This argument is built upon the fact that what affects people is not the how the physical environment is used, but the social and economic environment in which the physical environment is used.

Excluding the operators' experience in the production of space indicates the exclusion of the operators themselves from that process and emphasises what the planners and policy makers perceive to be appropriate. Following this exclusion, the informal livelihood operators become involved in the process of negotiating, especially the ones who contest and appropriate their claim to use particular places, and this process underlines their struggle. The operators' loss of such space is seen as a threat to their livelihood. Similar arguments can be found in Lefebvre's ideas about space becoming the principal stake of goal-directed actions and struggle (Lefebvre, 
1991).

This paper is therefore informed by the production of space as conceptualised by Lefebvre. The study looks at spatial practice: space as it is organised and used by different agencies that intervene in the process of creating a material entity. The representation of space as considered by Lefebvre, is the space created by planners. However since informality is gaining ground as the "mode of production" in terms of housing and land markets, it is logical to conclude that informal ways of spatial production are replacing the role of planners/architects. Politicians as independent agents facilitate or prevent the way informal operators produce their own space. Therefore it is important to note that in the global south the representation of space could be created by both planners and inhabitants, as suggested by Roy (2010). It is therefore useful to use the social production of space as a theoretical framework that provides a better analysis of how the appropriation of space by informal operators is undertaken, in terms of the generative process that results from the relations of those involved in the production of that space. This can allow an exploration of the process of producing space and the role of the various agencies involved. Looking at those agencies, it is interesting to consider what they do and how they do it. The social production of logical spaces for informal operators entails the ways in which the spaces are planned, materially and socially appropriated, designed and regulated by various actors involved in the process. In this process, the relationships between operators and urban spaces are redefined, resulting in a strong network. This not only redefines space in an abstract way, it also puts the space in question into a transitional state by imposing informal zoning principles, design and placements of objects. Another emphasis is placed on the representational space, which is focused on the actual use of space, or in Lefebvre's terms the lived space. This space is often referred to as the space of everyday life, which in the context of informal operators entails their use of road reserves, markets, pavements and pedestrian walkways for their livelihood activities. As I shall show in the analysis chapters, it is only by appropriating spaces that the operators' world is possible. Operators become tied to the prime locations in the city. In this sense the prime locations make the operators, just as the operators make the prime locations.

\section{Methods}

This article is based on a study of informal livelihood operators in the prime locations of Dar es Salaam city, which took place between June 2010 and December 2012. Owing to the nature of this research, which involves a contemporary phenomenon, with objectives and questions that focus on complex processes, relationships and human behaviour, a mixed method research approach was adopted. The data on the socio-economic characteristics of the informal livelihood operators, space characteristics, access to, and contests over, space; and access to finance, awareness and adherence to policies, rules and regulations is derived from a survey of 200 questionnaires administered face-to-face, which facilitated a $100 \%$ response rate by those who agreed to participate. Owing to the pattern of activity in the study area, the timing of questionnaire administration was divided into two temporal categories: day and night. The day category mainly took place in Mchikichini market and Uhuru Road, whilst the night category was along Msimbazi and Uhuru Roads. Since the day category included operators in both designated locations and undesignated locations, it was useful to administer more questionnaires in that category, so a total of 150 questionnaires were administered. The night category was restricted to 50 questionnaires only, as these interviewees were considered to work only in undesignated locations. The aim was to ensure that the operators interviewed represented the range of activities that took place. The operators were selected through convenience sampling, and if they accepted to participate in the survey, they were then taken through the whole process. A total of 43 in depth interviews of informal operators, shop owners, municipal officials and customers interviews were undertaken on the issues of access to space. From the professional side, the researcher interviewed a number of town planners and a business officer. On the academic side the researcher interviewed researchers experienced in urban management and development studies. The interviews were also conducted with the operators' association leaders. Some respondents were the same people who had already responded to the questionnaires. The detailed interview was carried out according to the same two temporal categories (of day and night).

Demographic characteristics of the respondents indicate that there are more male (85\%) than female Informal operators in prime locations of Dar es Salaam city. Young people aged between 20 and 30 years dominate the informal space, which, is more than half of people involved in such activities. It is also noted that more than half of the people involved are married which is an indication of the level of responsibility attended. Despite their 
majority income range of Tsh. $(0$ - 100,000) is low, making a honest living is a priority for the operators. Employment status is also essential for this particular group of people rather than being referred to as unemployed, men and women involve themselves in the production of spaces for their informal activities.

\subsection{Findings}

\subsubsection{Working in Prime Locations}

The basic features of informal livelihood activities include the flexibility of the sector, which allows operators to enter and exit easily, and plays a major role in the operator's decision to become involved in these activities. Informal livelihood operators reported having worked in a different job before selling merchandise in urban spaces. Nearly $70 \%$ of respondents in the case study area reported having previously worked doing manual labour such as carpentry, welding, building, domestic work, and road cleaning, while others reported having been previously employed in industries and other organizations. For those who moved into informal activities from domestic work or road cleaning, the idea of operating their own business, no matter how small, was a very appealing proposition, in contrast to working in other people's homes or cleaning the roads. One respondent explained:

"Look at me, now I have my own business; initially I used to sweep the road, you can imagine how hectic that job is. You will always inhale a lot of dust and end up in the hospital”. (Interview 3, with Aden (operator), 2010).

Others reported having left their jobs in anticipation of making a profit from informal activities. The majority (63\%) of respondents are willing to exit from the informal sector, but only if they were able to acquire better jobs, which paid them more than they are currently earning. However, $35 \%$ of respondents indicated that they are willing to continue working as informal operators, because they claim in doing so to make a profit which sustains their daily needs.

Sixty eight per cent of the respondents considered the ability to generate income to be worth the effort and competition for these prime spaces. For them, it is not a question of the right to public spaces, but rather of the right to locations, which attract customers and are also easily accessible, since there are many public spaces which do not attract passing trade within the city. The observations of Dar es Salaam city revealed that not all locations attract informal operators (Figure 1 and Figure 2). For example while the round about is used as a focal point, the streets further away from it are less appropriated, despite being in the central business districts.

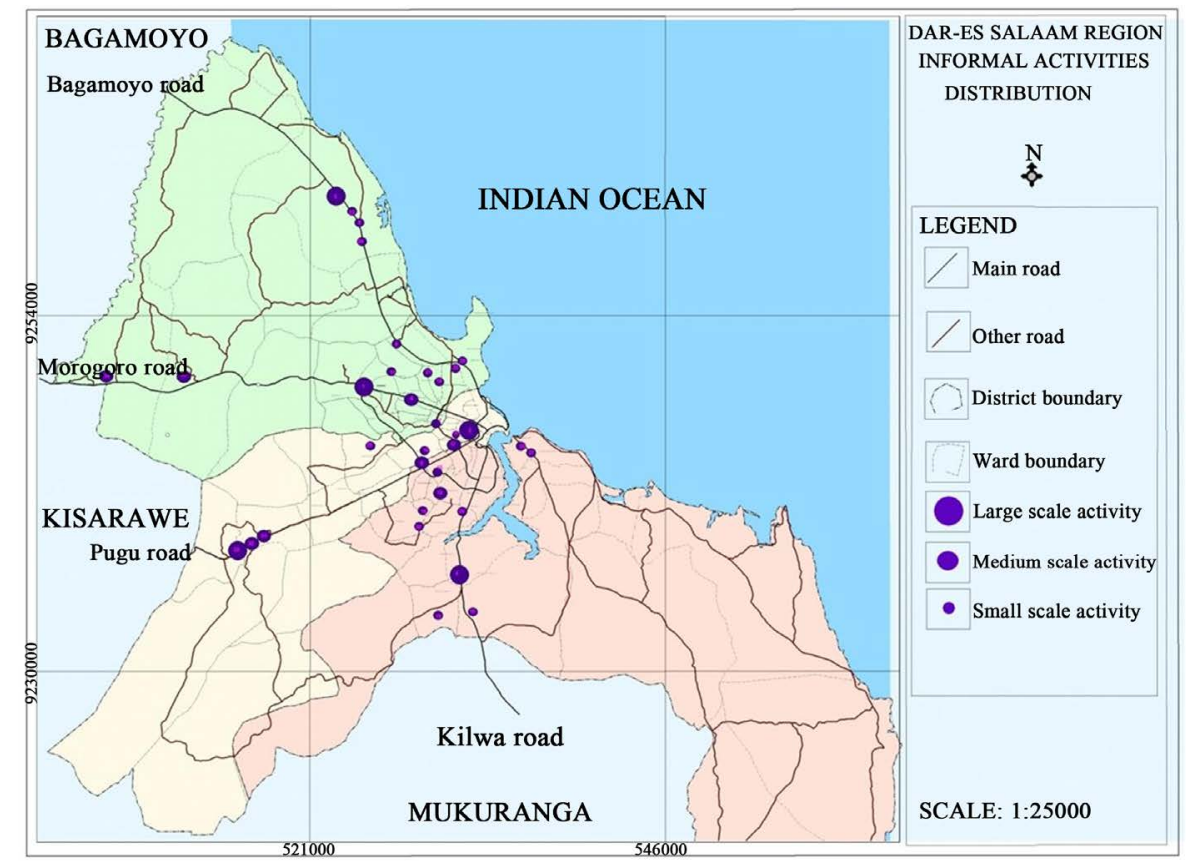

Figure 1. Dares salaam region: distribution of informal activities. Source: fieldwork June-September 2010. 


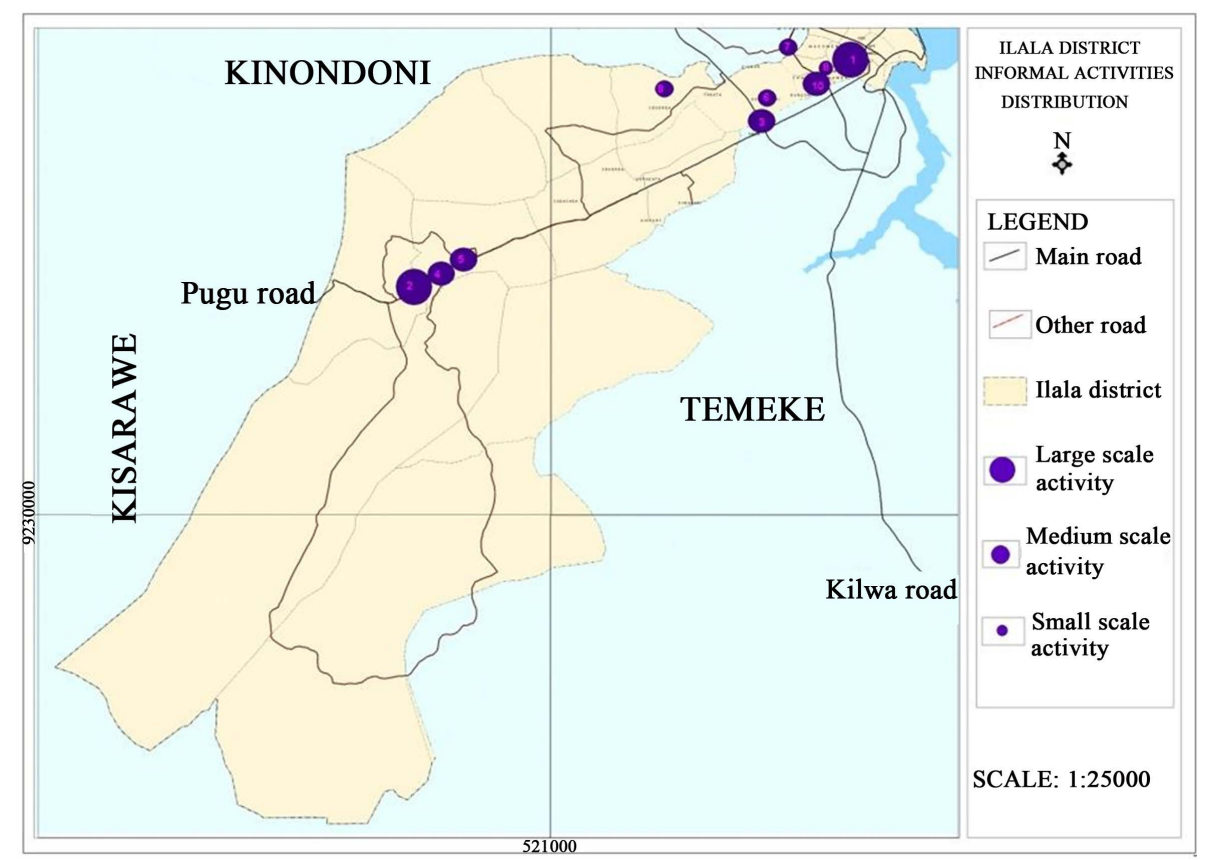

Figure 2. Ilala municipality: distribution of informal activities. Source: Fieldwork June-September 2010.

Even working space in the middle of Mchikichini market are less appropriated and sometimes abandoned. Another observation was made at Mlimani city shopping centre in Kindondoni District; the operators have gradually started appropriating the surrounding areas, in response to the routes of potential customers. This is where the ideas of land use and location theory provide useful insights to planners and designers. Formal businesses and offices are attracted to central locations and since they are able to bring in the highest rents, access to such locations is possible. Similar considerations are made by the informal livelihood operators; locations which yield the highest rents attract appropriation. Since economies of agglomeration are ensured by the presence of formal businesses, such locations correspondingly become the best choice for the operators.

\subsubsection{Location: Does It Make a Difference?}

The location of urban spaces plays a major role in informal livelihood activities (Savas, 1978; Richardson, 1984; Dewar \& Watson, 1990; Hays-Mitchell, 1994; Mitullah, 2003). The location of spaces which informal livelihood operators are attracted to are generally those with a good flow of customers, accessibility, range of goods, and safety and security. Ninety four per cent of the respondents revealed that the availability of customers is the main factor which they consider when selecting a given location for their operations. This study has also found that informal operators are interested in how much they sell per day. They are willing to use restricted spaces without fear, provided they can sell their merchandise. The best spaces for their activities are usually along busy streets and by parking spaces where the loading and unloading of passengers takes place. Within the study area, Msimbazi Street and Uhuru Street, in both directions, were particularly attractive to both operators and customers One customer explained:

These people are trying to earn a living and, because the municipality has failed to allocate space for them they should be left to do their business just like other people, personally I like buying from them as they sell their products at a cheaper price. (Interview 4, with Hashim (customer), 2010).

The dependence of informal operators on passing trade leads to the uneven distribution of their activities, not only within the city but also within the municipalities. This tendency affects the pattern of informal activities as they continue to concentrate in prime locations, mainly in the Central Business District (CBD) (Figure 1 and Figure 2). The informal operators' ability to persuade customers and provide cheaper products than shop owners has ensured availability of a market for their products and, hence, the sustainability of their activities. One customer explained: 
You see, I did not plan to buy this shirt but this operator has persuaded me to buy it. (Interview 3, with Ann (customer), 2010).

Besides products being sold at reasonable prices, customers also explained that buying from the operators is a way of assisting them to cater for their daily needs. One customer explained:

I buy merchandise from the informal operators because they are cheap, their service is quick and also partly to help them to cater for their daily needs. (Interview 1, with Asha, (customer), 2010).

\subsubsection{Who Decides on the Best Location for Informal Livelihood Operators in Prime Areas?}

The answer to the above question furnishes a clearer understanding of the basis for the formalization of spaces for informal livelihood activities. Formalization is the municipality's strategy for facilitating informal operators' access to working space. However the decision about where to locate such spaces within the prime area has not been the responsibility of the municipality. Since the Sustainable Dar es Salaam Project when stakeholders were involved, the decision was made to relocate the operators to peripheral markets. To ensure the operators moved, the decision was followed by municipal clean-up campaigns in 2000 and 2003, with the latest taking place in 2006. Operators were directed to the markets at Makumbusho and Kigogo Sambusa which were known to have failed to attract sufficient customers as well as informal operators. It was clear to the operators that they were unwanted in prime locations. However since the operators were not attracted to these alternative markets offered to them, they appealed to the Regional Commission who, after negotiating with them gave directives to allow them to operate in the then "botanical garden" which subsequently became the Mchikichini informal market. The municipal departments, as analysed in earlier sections in this chapter, were not part of that decision. Nevertheless they participated in the implementation. The question remains on what the role of the municipality is with regard to the decision on where to locate informal operators in the prime locations. Despite the collaborative approach adopted by the city and respective municipalities on pressing issues in the SDP or in administrative terms, "good governance", decisions relating to the precise location of informal operators are being made by political leaders. In addition, it seems that the political decision in most cases favours the presence of operators in prime locations, by contrast with the decisions made by municipal departments. Politicians seem to be dictating the decisions concerning informality in prime locations and playing a part in space transitions. Their influence also seems to extend to the location and construction of markets within the city, without fully considering the reasons for their failure up to now.

Political decisions are influenced mainly by the need for political support from the working poor. Operators make use of the desperation existing in the political sphere to advance their claim on prime locations. Ultimately the business location is decided by its operators; but their decision will be deemed either legal or illegal, depending upon how the municipality ascribes their choice.

\subsection{Space Transition}

The ability of the operators to possess the streets, parking spaces, and bus stops lead to the transformation of such locations. The following sections detail the changes which occur in spaces used by the informal livelihood operators.

\subsubsection{Flow of Customers and Operators to Mchikichini Market 6 am - 4 pm}

The discussion on the characteristics of urban spaces which attract informal operators, as presented in the previous section alludes to the transformations which take place in urban spaces as a result of those spaces being occupied by informal livelihood activities. This type of transformation is referred to as space transformation. There is a neat temporal transformation from one form to another which occurs in accordance with the time of day. The time specified in this study was from 6 am to $6 \mathrm{pm}$, when operators in designated areas are very active owing to the continuous movement of potential customers from other parts of the city. On each side of Mchikichini market, there are buses from all destinations which drop passengers who have come specifically to shop in this area (Figure 3). The close proximity with other shopping areas such as Kariakoo and Ilala Boma, encourages pedestrians to move through this area-at least those who are willing to walk to Mchikichini market to avoid extra transport costs (Figure 4). The spaces are fully occupied with both authorized and non-authorized operators, who take advantage of potential sales. The authorized space attracts customers at specific times, while 

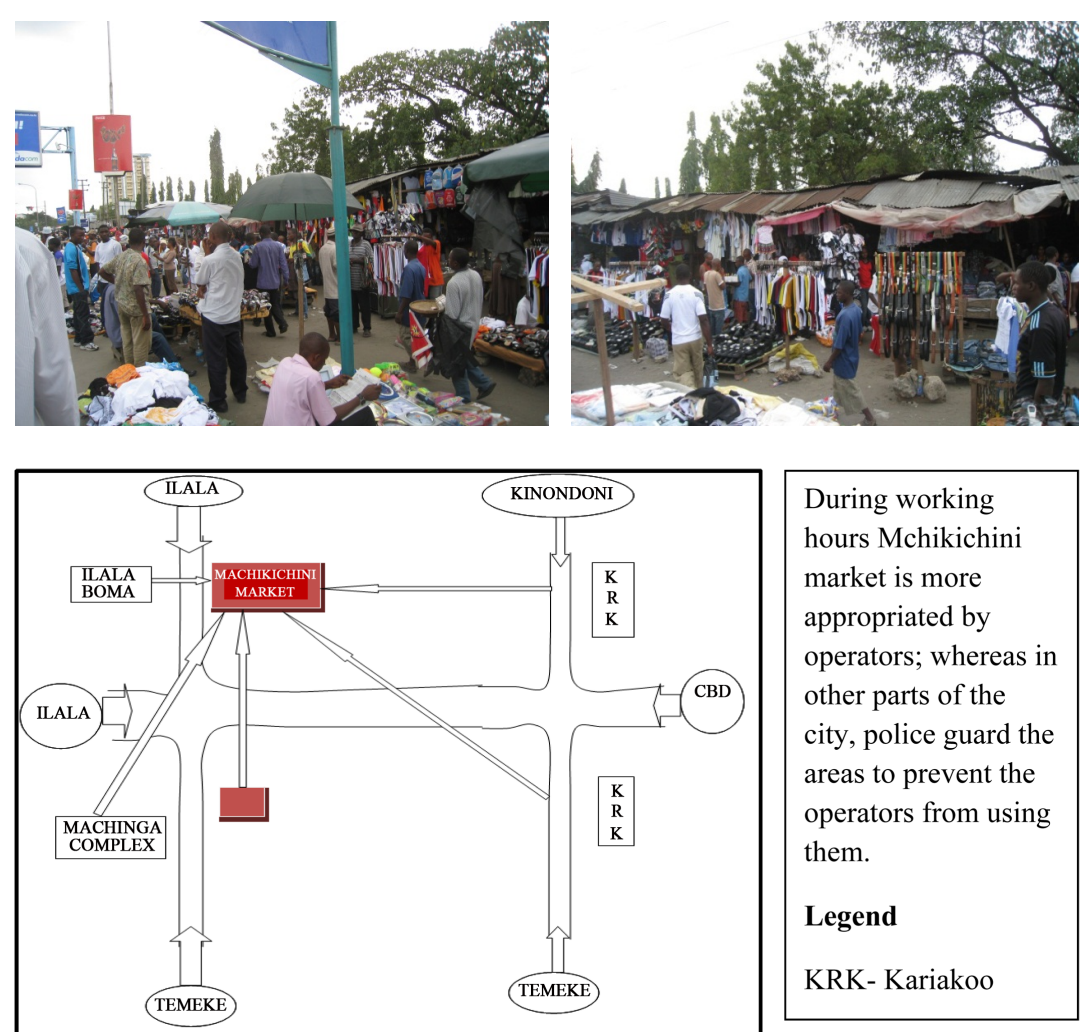

During working hours Mchikichini market is more appropriated by operators; whereas in other parts of the city, police guard the areas to prevent the operators from using them.

Legend

KRK- Kariakoo

Figure 3. Sketch of Flow of customers and operators to Mchikichini Market. Source: Fieldwork June-September 2010.
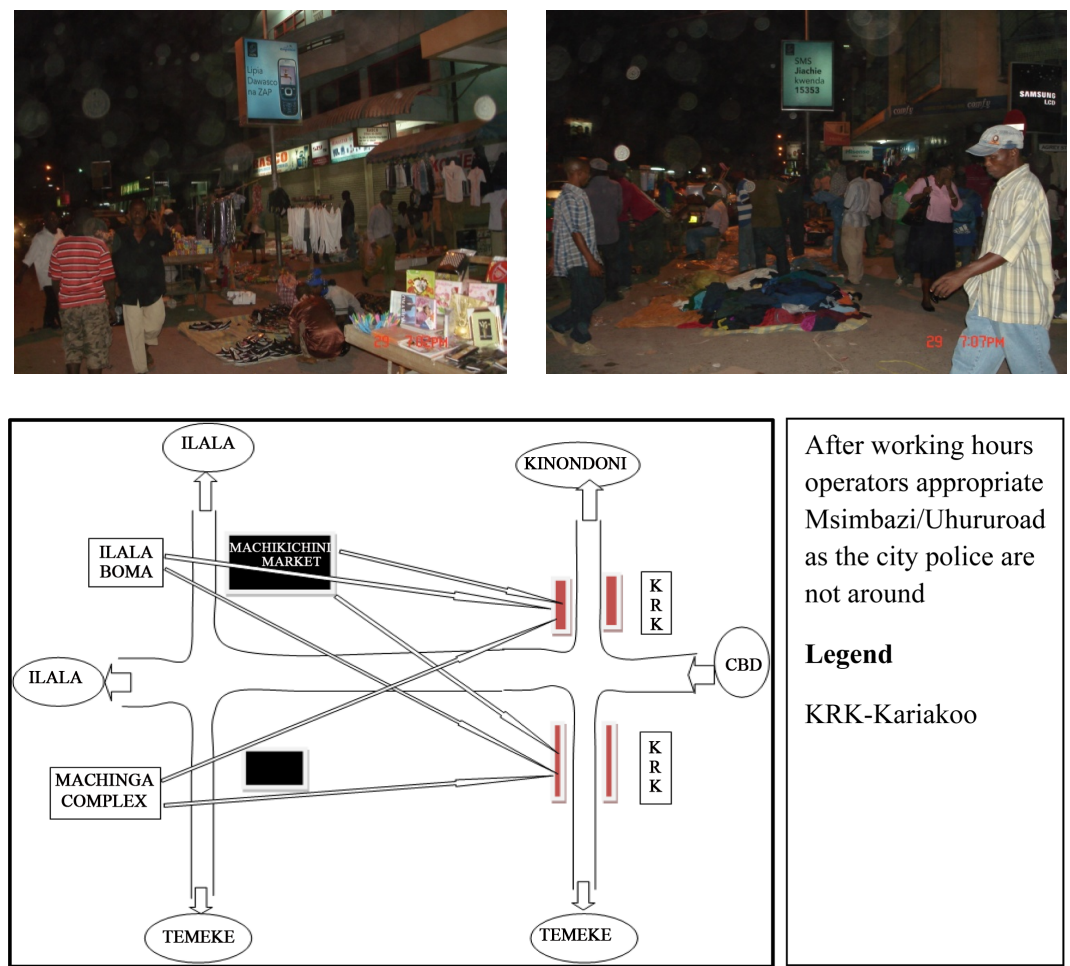

After working hours operators appropriate Msimbazi/Uhururoad as the city police are not around Legend KRK-Kariakoo

Figure 4. Sketch of Flow of operators to Msimbazi/Uhuru Roads. Source: Fieldwork JuneSeptember 2010. 
the unauthorized spaces are kept under surveillance by the municipal police until around 4:30 pm every weekday.

\subsubsection{Flow of Customers and Operators to Authorized Areas 4 pm - 12 am}

The placement of operators changes from $4 \mathrm{pm}$ to around $12 \mathrm{am}$, when operators start to relocate to unauthorized areas following customers' movements as they travel back to their places of residence (Figure 4). These changes determine the meaning of these prime locations. As noted by Kidder (Kidder, 2009: p. 310) "space is an experienced set of material practices", from which meanings are assigned, for instance those operating the streets' informal livelihood activities are generally perceived to be undesirable in prime locations, while pedestrian movements is perceived to be an appropriate and desirable use; this has consequently become the way space is perceived. Nevertheless space is not only "determining but also can be determined; space as it is lived can be appropriated by the user against intended conceptions" (Kidder, 2009: p. 310). While the municipality appropriates space for pedestrian movement and parking, the operators react with counter-appropriation, altering the timeframe for their appropriating activities. By doing so they not only redefine space, but also transform material space by imposing their own zoning principles (the same kinds of products are gathered alongside one another in the space, for example, agricultural produce, second hand clothes and other manufactured merchandise), and positioning temporary objects such as push carts and sack cloths. Informal operators, therefore, transform prime locations from highly restricted spaces to areas where they can sell their merchandise and hence make a living.

\subsubsection{Emerging "New City"}

The appropriation of prime locations for informal activities has formed a "new city". Night markets are an emerging phenomenon across Dar es Salaam city. Their origin can be traced to the year 2006 when informal operators experienced major eviction following the 2005 general election. By mid-2005, a massive invasion of prime space by informal livelihood operators had taken place. Operators took advantage of the mass presence and where possible erected structures, conducting their business wherever they chose to undertake it. In early 2006 after the new government took office, the Prime Minister issued a statement ordering informal operators to vacate the premises which they had invaded over the last year. The municipal authority undertook a massive overnight clean-up programme, during which they cleared all the structures away and moved all the operators on to other places, albeit not of the operators' choice. In this way, the municipality managed to drive the informal livelihood operators out of prime spaces.

However, it was not long before the informal operators came up with their own innovation on how to continue operating in these prime spaces. They gradually returned to occupy these spaces in the evenings, mainly from 4:00 pm onwards. The strategy was twofold: to target their merchandise at potential customers who were coming home from work, as well as targeting prime spaces around established shops once these had closed for the day. This phenomenon started along Msimbazi Road, which is famous for agricultural produce such as fruits and vegetables as well as a variety of other manufactured goods. Although the street would be empty in the morning and throughout the afternoon, from $4 \mathrm{pm}$ onwards, it would be teeming with informal operators as well as potential customers (Figure 5). Figure 3 and Figure 4 also illustrate how operators have transformed space in the
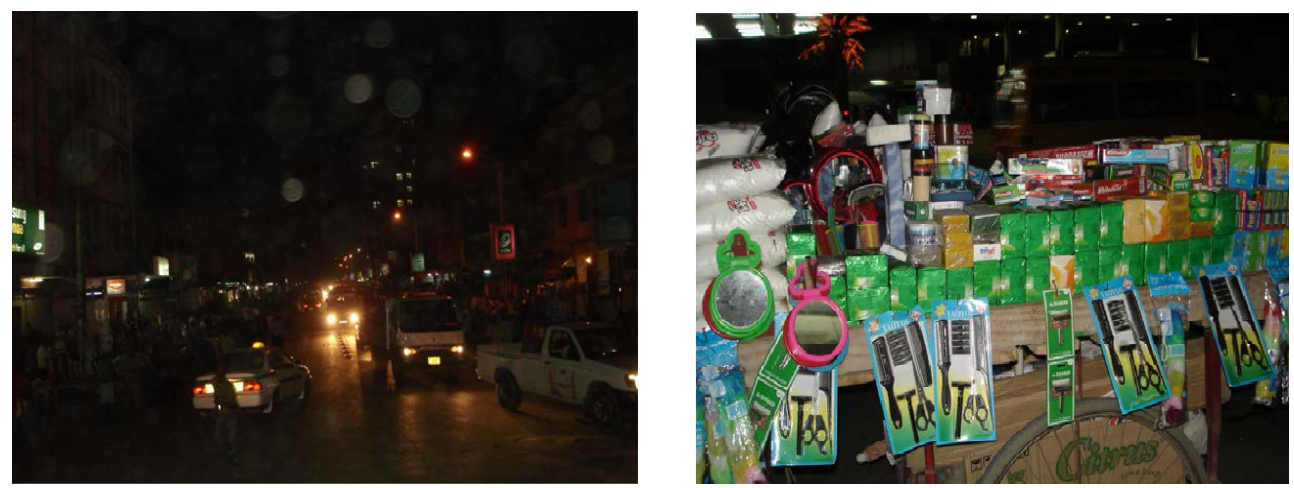

Figure 5. Occupation of streets during the night, Msimbazi/Uhuru road. 
study area. This observation go beyond the study area for instance, in places such as Ubungo bus terminal, and on both sides of Mandela Road, Morogoro Road and Sam Nujoma Road, traders appropriate the space for their activities. Some operators conduct their business up to 10:00 pm, while others continue up to midnight. Operators who continue to work until midnight tend to be those selling coffee and groundnuts. The municipality, as well as the city authority, seems reluctant or unwilling to address this phenomenon.

The shift to the night market is the result of competition for the same space by various stakeholders. Some shop owners demand that the municipality should drive away informal operators to avoid unfair competition as well as to ensure that the space is left empty to allow both shop owners and their customers to park their cars as well as allow pedestrian movement and reduce congestion. The municipality is also keen to keep the environment clean by ensuring that operators do not block the drainage systems with solid waste (interview with a member of the environmental working group, Ilala Municipality, 2011). They are also interested in making sure that there is no congestion around these areas. All this is part of the municipality's agenda to keep the city clean and to make it competitive in the global market for attracting investment and tourism activities. The question that arises is whether or not these endeavours are valid only during the day. The concerns that motivate the formal and public sectors have all contributed to the informal operators' strategy of developing night markets so that they can continue to sell their merchandise and generate income for their daily livelihood in the city.

Whilst conducting a general overview of the city and its informal operators, it became clear that time factors influence operators with regard to what merchandise they sell and which approach to take to selling it. Operators have developed a tendency to alter the type of products they are selling in accordance with the time of the day. For example, during the morning rush hour when urban dwellers are on their way to work, informal operators tend to sell merchandise which their potential buyers may require at the workplace, whilst the evening stock of merchandise tends to comprise products that would be more useful for domestic use. Hence access to space in the right strategic direction as well as having the right merchandise at a particular time of day is essential for informal operators. The concentration of operators along the streets also varies with respect to what they sell. In the morning they concentrate on streets leading to workplaces while in the evening the operators tend to concentrate on routes leading to residential areas. This is a strategic way of doing business to ensure that they can maximise sales of their merchandise and thus make a livelihood.

The recent response towards the relocation, eviction and harassment of informal livelihood operators has included the alteration of working hours and, as elaborated above, the formation of a "new city". In Latin America, a study of the case of Cusco, Peru showed how informal livelihood operators have responded to eviction by inventing new markets in their backyards (Bromley \& Mackie, 2009). All this demonstrates how innovative informal operators can be in accessing strategic spaces to ensure that their livelihood is sustained.

\subsubsection{On the Move or Here to Stay?}

Although operators use temporary structures and temporary locations, there is no indication that they would consider using the peripheral locations provided by the municipality. However interviewees revealed that they would consider relocating to other preferred locations such as Mwenge and Ubungo, which are located in Kinondoni municipality, as one of the respondents explained during the interview:

I am willing to relocate to either Mwenge or Ubungo if I get access to working space. (Interview 4, with Herry (operator), 2010).

It is important to note that the competitive advantages offered by prime locations would nevertheless continue to drive them to seek access to these areas. In addition, changes to the provision of shelters and structures would not necessarily meet with the operators' satisfaction. Operators perceive themselves to be capable of doing the right thing when given the right direction.

\subsection{A Discussion of the Key Findings and Their Implications}

The following section provides a cross examination of the findings and their relationship to the wider debate on similar issues.

\subsubsection{The Operators in Perspective}

It appears that the experience of individual operators acts as an enabling factor in the decision to access prime 
locations. Through the experience operators acquire over time, they are able to establish a social network which is essential if they are to gain knowledge of the available working spaces in a particular location. Experience within the city environment and the establishment of contacts are important considerations when informal operators are looking for a working space. This finding corroborates the work of Companion (2007) which showed that experienced informal operators in Ethiopia enjoy distinctive advantages in gaining access to merchandise for sale. Similar to these findings, a study in Mexico City demonstrated the importance of networking, which was found to provide added value to the operator (Peña \& Frontera Notre, 2000). A similar account of the value of networking was highlighted by Lyons (2005), who referred to the concept of social capital as evident in Kenya. The experience gained through these networks provides avenues for traders to increase their advantages, either in terms of access to space, merchandise or in other issues related to their operations. The place of origin of informal livelihood operators has dominated studies of the informal economy since the 1980s, with scholars arguing that informal operators tend to be migrants from rural areas (Todaro, 1976). Operators are still likely to be from rural areas and the informal sector remains their main mode of employment (Cornwell \& Inder, 2004). However recent migrants face limitations in accessing the prime locations as detailed in this study. This study has found that informal livelihood operators working at the heart of the city seem to have lived in Dar es Salaam for more than five years and to have previously experienced eviction or relocation from a workplace. This study suggests that experience within the city environment is a vital factor in the process of accessing prime urban spaces for informal livelihood activities and this experience is established through networking ranging from family members, relatives, friends and others, an aspect which was also noted in the ILO study of Zambia and Thailand (ILO, 2004).

\subsubsection{The Operators and Their Working Conditions}

Prime spaces attracting informal operators are endowed with a flow of potential customers, accessibility, a range of goods, safety and security. Operators take these criteria into consideration when selecting a location for their businesses, in order to maximise their income-generating activities. The location does not necessarily have to include a shelter. It is common practice for informal operators to operate in parking spaces, bus stops, pavements and along the streets, even though sheltered market buildings are made available to them. For instance in Peru, Zambia, Kenya, and Mexico, operators have rejected the market buildings made available to them, preferring to operate in alternative spaces of their own choice (Peña \& Frontera Notre, 2000; Bromley \& Mackie, 2009; Hansen, 2010). The main interest of the operators centres on pedestrian "footfall" and how much they can sell per day; hence they are willing to act against the wishes of the authorities by appropriating space for their operations. Similarly, a study by Kidder (2009) found that bike messengers' appropriation of space went as far as violating traffic regulations in order to archive the ultimate goal of making their deliveries on time.

\subsubsection{The Spaces and What Shapes Them}

The presence of operators in prime locations redefines the landscape of the city and that is why the local authority sees operators as a source of "uncleanliness of the municipal environment". Kamete (2010) also found that informal operators tend to be labelled as "filth" and, hence, they are unwanted in urban space. The presence of informal operators presents a landscape which is not supported by planning regulations or the municipality's vision of the city. This study suggests that despite being unwanted in urban spaces, operators do everything in their power to stay in the urban areas of their choice. A location which attracts passing trade is useful for informal activities. The importance of location is propounded in central place, location and land use theory. However in their occupation of central spaces, operators add the aspect of illegal appropriation, as they are unable to pay the highest rents. This lived experience provides the meaning of space, as Lefebvre argues: "space can only be understood as something that is lived" (Lefebvre, 1976: p. 362; Lefebvre, 1991). Space as it is lived can be appropriated against the intended conceptions (Kidder, 2009). Operators in these urban spaces seem to be there to stay. They are fighting unfair distribution resulting from the production of space (Watson, 2002). The phenomenon of operators along the streets who have been ignored by municipality systems suggests the need to address their concerns using core arguments from Just City theory, which is about ensuring the distribution of planning outcomes to other urban space stakeholders. If applied appropriately in the process of producing urban spaces, this can make it more likely that inclusiveness will be achieved in the distribution of planning outcomes, with the result that the city landscape will be produced in a way that takes into account the needs of all stakeholders in the prime urban realm. 


\section{Conclusion}

In this paper the production of spaces for informal livelihood activities was investigated. Involvement in informal livelihood activities provides operators with the ability to generate income, change their employment status, and create networks which contribute to their well-being. The discussion revealed that the challenges posed by the inadequate provision of working spaces which attract passing trade, are accessible, have access to a range of goods, as well as safety and security; force operators to run their activities in both designated and undesignated locations. Networks established among other informal operators, and factors including experience within the city environment, provide them with a competitive advantage in terms of access to knowledge about availability of working spaces with adequate passing trade. The ability to appropriate such locations allows for the material transformation of a particular locations' landscape, which engenders conflict with both the local authority and other stakeholders of urban space. Their profound interest in prime locations of which the bid rent is beyond their means has made the process of appropriation more difficult and hence requires an innovative approach with regard to how to gain access to such locations. Understanding these lived experiences with regard to why the appropriation of prime locations is necessary for these operators can equip planners and designers with a framework which allows for a more equitable distribution of the benefits of urban space in their plans and policies.

The long-established land use, central place and location theories providing a basis for understanding spatial organisation of activities and people. Although on-going technological developments in terms of transportation and communication put into question the relevance of these theories, this basic understanding is still appropriate in cases such as identifying the location for informal livelihood activities. Through this lens, this study has expanded understanding of the informal mode of production of space by identifying the factors which attract operators to a particular location. However, the meaning of the informal mode of production of space is also produced and reproduced through the formal system. The Mchikichini market case shows operators' ability to identify such a location and negotiate its occupancy as a powerful alterative way of producing space for informal activities. The locational advantages of this market lie in its being in close proximity to the Kariakoo shopping area and the Ilala and Buguruni areas, which are densely residential areas; in there being two markets in close range to this market; and in its accessibility from all parts of the city-together these factors have made it a perfect location for informal livelihood activity. The operators managed to subdivide working space in that area and to materially appropriate it by constructing their own vending structures, up to the point where the municipality intervened in the operation. The municipal intervention has, however, been criticised by operators when it questioned the subdivision which had already taken place. This has shown that operators know what they need and how to achieve it. The Mchikichini market is one of the successful markets to be established in a prime location since the municipality started working on informal economy issues. The production of space for informal livelihood activities is part of social, social-political and socio-economic processes which allow informal operators to sustain their livelihoods.

Production of space extends to the creation of a new city which occurs after normal business hours. The informal operators materially appropriated space by providing their own vending structures and, through informal management arrangements, protected the location and hence considered it their own. Municipal officials have so far appreciated the initiative of these innovations and have applied in-time arrangements with the operators for them to continue working in these locations. This study suggests that decisions about where to locate informal activities reached by the operators themselves, based on their lived experience, should be given priority in this process of space production, to reduce cases of harassment and a waste of the resources involved in the whole process. Despite the historical rhetoric framing these activities as “undesirable elements” in Dar es Salaam city, as noted by Burton (2005), the space occupied by informal operators continues to shape the city landscape. Roy (2010) highlights the informal production of space which is evident in less-developed countries. Although Roy's focus was on informal settlement development, her claims could be extended to informal livelihood activities, using the examples of the two cases presented above. The material appropriation and social appropriation of prime locations by operators provides the basis for extending this claim. The formal mode of space production has shaped the way society understands informal activities and operators. The socio-economic characteristics of an individual play an important role in the way production and consumption of urban space is perceived. Cross and Karides (2007) also agree that informal activities help to shape spatial organization.

In Dar es Salaam, the production of space and who should have access to space is controlled by the Urban Planning Act (2007) and the authority responsible for this production is the municipal authority under the Land and Town Planning Department. Section 19 of the Urban Planning Act (2007), advocates for stakeholder partic- 
ipation in the production of space. This could be strengthened by considering the lived experience of the operators, and in particular considering the informal mode of production of space, as until recently the implications of this Act on informal livelihood activities have remained largely unconsidered by the planning and design discipline. This thesis suggests exploring the spatial organisation of informal activities from an informality perspective. The basic principles of location and central place theory can continue to be used and to shed light on the actions of municipal personnel responsible for planning issues. This approach provides some remedies to the problem of inaccessible spaces which do not necessarily conflict with the legislative system, economic development opportunities and design techniques. The production of space through informal mode processes occurs every day at different scales, be it in housing markets, settlement development or market transactions. Therefore integrating these activities into the city-wide economy requires an enabling environment which does not necessarily have to decentralise the activities to peripheral areas but rather depends upon critically interpreting the existing everyday practice of informal operators, such as cooperation with other individuals, family, friends, customers and established shop owners who assist them in establishing the material and social appropriation of space.

\section{References}

Beall, J., \& Fox, S. (2009). Cities and Development. Abingdon and New York: Routledge.

Bromley, R. D. F., \& Mackie, P. K. (2009). Displacement and the New Spaces for Informal Trade in the Latin American City Centre. Urban Studies, 46, 1485-1506. http://dx.doi.org/10.1177/0042098009104577

Burton, A. (2005). African Underclass: Urbanisation, Crime and Colonial Order in Dar es Salaam. Oxford: James Currey.

Companion, M. (2007). Adaptability and Survival: A Case Study of Street Vendor Response to Famine Conditions in Ethiopia, 1999. In C. J. Cross, \& A. Morales (Eds.), Street Entrepreneurs: People, Place and Politics in Local and Global Perspective (pp. 223-244). London and New York: Routledge. http://dx.doi.org/10.4324/9780203086742.ch13

Cornwell, K., \& Inder, B. (2004). Migration and Unemployment in South Africa: When Motivation Surpasses the Theory. www.csae.ox.ac.uk/conferences/2004.../5f-Cornwell-CSAE-2004.pdf (Accessed: Retrieved January 21, 2011, from Scholar Google)

Cross, C. J., \& Karides, M. (2007). Capitalism, Modernity, and the “Appropriate” Use of Space. In C. J. Cross, \& Morales, A. (Eds.), Street Entrepreneurs: People, Place, Politics in Local and Global Perspectives (pp. 19-35). London and New York: Routledge.

Dewar, D., \& Watson, V. (1990) Urban Markets: Developing Informal Retailing. New York: Routledge.

Gans, H. J. (2002) The Sociology of Space: A Use-Cantered View. City and Community, 1, 329-339. http://dx.doi.org/10.1111/1540-6040.00027

Gieryn, T. J. (2002) What Buildings Do. Theory and Society, 31, 35-74. http://dx.doi.org/10.1023/A:1014404201290

Hansen, K. T. (2010) Changing Youth Dynamics in Lusaka's Informal Economy in the Context of Economic Liberalisation. African Studies Quarterly, 11, 13-27.

Hays-Mitchell, M. (1994). Street Vending in Peruvian Cities: Spatial-Temporal Behaviour of Ambulates. Professional Geographer, 46, 425-438. http://dx.doi.org/10.1111/j.0033-0124.1994.00425.x

Hirt, S. A. (2009). Premodern, Modern, Postmodern? Placing New Urbanism into Historical Perspective. Journal of Planning History, 8, 248-273. http://dx.doi.org/10.1177/1538513209338902

ILO (2004). Role of the Informal Sector in Coping with Crisis in Thailand and Zambia. Geneva: International Labour Organisation.

Kamete, Y. A. (2008). Planning versus Youth: Stamping out Spatial Unruliness in Harare. Geoforum, 39, 1721-1733. http://dx.doi.org/10.1016/j.geoforum.2008.06.001

Kamete, Y. A. (2012). Interrogating Planning's Power in an African City: Time for Reorientation? Planning Theory, 11, 6688. http://dx.doi.org/10.1177/1473095211419116

Kerr, D. (1994). The Time of Trial by Space? Critical Reflections on Henri Lefebvre's Epoch of Space. Common Sense: Journal of Edinburgh Conference of Socialist Economists, 15, 18-35.

Kidder, J. L. (2009). Appropriating the City: Space, Theory and Bike Messengers. Theory and Society, 38, 307-328. http://dx.doi.org/10.1007/s11186-008-9079-8

Lefebvre, H. (1976). The Production of Space. Oxford: Blackwell.

Lefebvre, H. (1991). The Production of Space. Oxford: Blackwell.

Lyons, M. (2005). Creating Social Capital: Some Evidence from Informal Traders in Nairobi. Urban Studies, 42, $1077-1097$. http://dx.doi.org/10.1080/00420980500120865 
Mabogunje, A. L. (1990). Urban Planning and the Post-Colonial State in Africa: A Research Overview. African Studies Review, 33, 121-203. http://dx.doi.org/10.2307/524471

Mitullah, W. V. (2003). Street Vending in African Cities: A Synthesis of Empirical Findings from Kenya, Cote D'ivoire, Ghana, Zimbabwe, Uganda and South Africa. Background Paper for the 2005 World Development Report, Washington DC: World Bank.

Peña, S., \& Frontera Notre, C. E. (2000). Regulating Informal Markets: Informal Commerce in Mexico City. International Journal of Sociology and Social Policy, 20, 37-67.

Perry, D. C. (2003). Making Space: Planning as a Mode of Thought. In S. Campbell, \& S. S. Fainstein (Eds.), Readings in Planning Theory (2nd ed., pp. 142-165). Oxford: Blackwell.

Richardson, H. W. (1984). The Role of the Informal Sector in Developing Countries: An Overview. Regional Development Dialogue, 5, 3-40.

Roy, A. (2010). Informality and the Politics of Planning. In J. Hillier, \& P. Healy (Eds.), The Ashgate Research Companion to Planning Theory: Conceptual Challenges for Spatial Planning (pp. 87-108). Aldershot: Ashgate Publishing Limited.

Savas, E. S. (1978). On Equity in Providing Public Spaces. Management Science, 24, 800-808. http://dx.doi.org/10.1287/mnsc.24.8.800

Šliužas, R. V. (2004). Managing Informal Settlements: A Study Using Geo-Information in Dar es Salaam, Tanzania. Unpublished PhD Thesis, Utrecht: Utrecht University and ITC.

Soja, E. W. (1989). Postmodern Geographies: The Reassertion of Space in Critical Social Theory. New York: Verso.

Sparks, D. L. (2010). Informal Sector in Sub-Saharan Africa: Out of Shadows to Foster Sustainable Employment and Equity? International Business and Economics Research Journal, 9, 1-12.

Talvitie, A. (2009). Theoryless Planning. Planning Theory, 8, 166-190. http://dx.doi.org/10.1177/1473095209102233

Todaro, M. P. (1976). Internal Migration in Developing Countries. Geneva: International Labour Office.

UnWin, T. (2000). A Waste of Space? Towards a Critique of the Social Production of Space... Transactions of the Institute of British Geographers, New Series, 25, 11-29. http://dx.doi.org/10.1111/j.0020-2754.2000.00011.x

Verick, S. (2006). The Impact of Globalization on the Informal Sector in Africa. Addis Ababa: UNECA.

Watson, V. (2002). The Usefulness of Normative Planning Theories in the Context of Sub-Saharan Africa. Planning Theory, 1, 27-52. http://dx.doi.org/10.1177/147309520200100103

Watson, V. (2009) Seeing from the South: Refocusing Urban Planning on the Globes’s Central Urban Issues. Urban Studies, 46, 2259-2275. http://dx.doi.org/10.1177/0042098009342598 